\title{
PROSPECTIVE COOPERATION OF UZBEKISTAN WITH THE EUROPEAN UNION
}

\author{
Ismatullayev Farhodjon Odiljonovich \\ Doctoral student of Tashkent State Pedagogical University, \\ specialty 07.00.01 - History of Uzbekistan. \\ Candidate of Historical Sciences, \\ Associate Professor
}

Article DOI: https://doi.org/10.36713/epra6026

\begin{abstract}
The article analyzes some aspects of the development of trade, economic, cultural and humanitarian relations of the Republic of Uzbekistan with European countries. The author has demonstrated on the basis of evidence that these relations take place, especially in the framework of the Days of Economics, Investment, Literature, Science and Culture.

KEY WORDS: Republic of Uzbekistan, European Union, cultural and humanitarian cooperation, literature, trade and investment relations, art exhibitions, friendship society, research, cultural heritage.
\end{abstract}

\section{INTRODUCTION}

At the beginning of the XXI century, radical political and socio-economic changes have taken place in the world. As a result, relations between the countries of the world have changed radically, and a wide range of opportunities has opened up for the formation of a new system of international relations based on democratic principles.

The Republic of Uzbekistan, as an integral part of the world community, occupies a special place with its active participation in the formation of a new system of international relations. In this regard, first of all, in the first years of independence, work is being done on the basis of clearly defined strategies, principles and priorities of Uzbekistan's foreign policy.

From the first years of independence, Uzbekistan has identified cooperation with the European Union and its member states as one of its foreign policy priorities. Relations between Uzbekistan and European countries are developing within the framework of the Partnership and Cooperation Agreement between the Republic of Uzbekistan and the European Union and its member states, which entered into force on 1 July 1999.

\section{RESEARCH METHODS}

The research was conducted using objectivity, analysis, synthesis, comparative analysis, generalization, historical analysis, chronological methods.

\section{RESULTS}

Cooperation between Uzbekistan and the United Kingdom "On Trade and Economic Cooperation" signed on November 22-25, 1993 during the visit of the first President of Uzbekistan IA Karimov to the United Kingdom It is based on the agreements on "strengthening and mutual protection" and "on the avoidance of double taxation" [1].

Consistent cooperation can be seen in the official visit of the British Foreign Secretary Alan Donkan to Uzbekistan in December 2016. Foreign Minister Alan Duncan met with President of the Republic of Uzbekistan Sh. Mirziyoyev to analyze the current state of bilateral relations and agree on future plans. Alan Duncan stressed that London is also interested in developing mutually beneficial cooperation with Uzbekistan, the largest country in Central Asia.

As of 2017, 22 legal agreements serve as a basis for the development of bilateral trade, economic and cultural ties. Economic relations, in particular, have been growing year by year. In 2009, the 
bilateral trade turnover amounted to 37.3 million US dollars. USD [2]. This means that the United Kingdom ranks second in terms of Uzbekistan's trade turnover with the European Union [3].

The UK is one of the world's leading countries in the development and implementation of the digital economy and artificial intelligence. A workshop on "Digital Government Transformation in Uzbekistan: The UK Experience" was held on 29-31 October 2019 to learn about the UK's achievements in this area. The seminar was attended by the British Ambassador Timothy Torlot and experts in the field of digital economy $\mathrm{V}$. Pak and $\mathrm{K}$. Muhammadkhanova, who shared the latest research and achievements in this area. Many countries around the world, including South Korea, Japan, France, and the United States, are making great strides in the digital economy and artificial intelligence.

Uzbekistan has also paid great attention to the development of this area and raised it to the level of state policy. This is evidenced by the fact that the Republic of Uzbekistan has declared 2020 the Year of Science, Education and Digital Economy.

Uzbekistan exports cotton fiber, precious stones, ferrous metals, tungsten and their products to the UK, while the UK exports mechanical and electrical equipment, sugar and confectionery, plastic and plastic products, mineral fuels and pharmaceuticals. including pharmaceuticals, paper and cardboard, furniture, optical instruments and apparatus, tobacco, dairy products, chemical compounds, inorganic chemical products [4].

Bilateral relations with Germany have traditionally been wide-ranging and multi-faceted. A solid legal framework for cooperation has been created.

Diplomatic relations between the two countries were established in 1992 and have made great strides over the past quarter century. During the years of independence of Uzbekistan, stable cooperation has been established with Germany in political, economic, cultural, humanitarian and other spheres. Today, the two countries have a solid legal framework of more than 130 documents and a reliable mechanism for relations at all levels [5].

In the development of bilateral relations, President of Uzbekistan Sh.M. Mirziyoyev's visit to Berlin on January 20, 2019, opened a new era in the history of relations. During the visit, the achievements of the last quarter of a century were analyzed and it was noted that in the future it is necessary to consistently develop socio-economic and cultural-humanitarian ties. In bilateral relations, specific areas for expanding cooperation in the fields of culture and arts, tourism, science and technology, education, trade and economic, investment and technology, human rights have been identified[6].

There are 132 firms and companies with German investors in Uzbekistan. 33 of them are based on $100 \%$ German capital, 31 of them have opened their representative offices in our country. The National Bank of Uzbekistan TIF has established contacts with 57 German banks[7].

Germany is one of Uzbekistan's main trade and economic partners in Europe. Germany is one of Uzbekistan's key partners in technology and investment. Germany plays a special role in the country's economic and cultural cooperation with the European Union [8]. The two countries have introduced the most trade facilitation system. In 2017, the Uzbek-German trade turnover amounted to 613.2 million US dollars, in January-November 2018 - 712.1 million US dollars. USD. In 2019, this figure is expected to reach 1 billion euros. The total volume of financial and technical cooperation between the two countries exceeded 329.9 million euros[9].

There is a great interest in studying German culture and language in Uzbekistan. German is the second most widely spoken foreign language in the country. Currently, partnerships are established with more than 30 German universities in the field of higher education, with the exchange of students, professionals and teachers. Tashkent and Berlin in the development of bilateral cultural and humanitarian relations, Cooperation between Samarkand and Bremen, Bukhara and Bonn plays an important role.

Uzbekistan's relations with Spain, one of its most promising and promising partners in Europe and internationally, are developing rapidly.

At the invitation of the Minister of Foreign Affairs of Spain H.M. Garcia Margalio, a delegation led by the Minister of Foreign Affairs of the Republic of Uzbekistan visited Spain on November 4-7, 2013. During the visit, political consultations of the Foreign Ministries were held. Spanish Foreign Minister HM Garcia Margalio visited Uzbekistan on April 20-22, 2014. On November 12-15, 2017, the Minister of Foreign Affairs of the Republic of Uzbekistan paid a return visit to Spain.

The Uzbek State University of World Languages has a Spanish language faculty. The university's cooperation with the universities of Madrid, Granada, Alkala de Enares and Malaga is developing rapidly.

Uzbekistan sees Austria as a long-term and promising partner in Europe.

In a short period of time, Uzbek-Austrian cooperation has developed in economic, scientific, technical and cultural spheres [10]. Economic and trade relations between Uzbekistan and Austria are developing year by year. If we look at the trade turnover between the two countries, we can see that compared to 1997, its volume amounted to 75 million. More than USD. The list of exports from Uzbekistan to Austria includes food products, cotton, oil and oil products, chemical products and other similar goods.

In turn, new types of machines, equipment and vehicles are being imported from Austria to Uzbekistan. 
Relations between the two countries are also developing in the field of music culture. In particular, Austrian masters of music are actively participating in the annual International Music Festival "Sharq Tarona" in Uzbekistan [11].

The Ministry of Culture of the Republic of Uzbekistan, the Academy of Arts of Uzbekistan, the Research and Production Center for Arts, Crafts and Applied Arts "Musavvir" jointly with the Secretary General of the Austrian Society "Hammer-Purgstal" Z. Negotiations with Haas resulted in the establishment of the Days of Uzbekistan in Austria in April 2004[12]. As part of the Days of Culture, concerts of Uzbek music and dance groups, works of folk art and exhibitions of Uzbek artists were presented to the Austrian public.

Head of the Department of Culture of the Austrian Vienna Masters X. In accordance with the agreement reached with the Ministry of Culture and Sports of the Republic of Uzbekistan in 2003, in late September-early October 2005, 6 classical singers performed on tour. In turn, in early September 2005, the Vienna magistrate expressed his readiness to host a group of 15 Uzbek folklore artists in Austria. It is planned to be held in Austria as part of the Days of Culture of Uzbekistan, enriched with additional cultural events[13].

France is one of Uzbekistan's important partners in Europe. The sphere of culture plays a special role in the development of bilateral relations.

There have been several official visits between the two countries over the past period. During the visits, various cultural and educational expressions were presented. In particular, on the occasion of the visit of French statesman François Mitterrand in April 1994, works by French artists kept in the fund of the Museum of Art in Uzbekistan were exhibited. The State Museum of Art houses 45 paintings, including those by the famous French painter Renoara Claude It belongs to Mane, Cézanne, Dega Tissaro, Gogena Mattisa, Van Goga, Leje Braca [14].

A similar cultural dialogue continued at the Louvre during the visit of President of Uzbekistan Sh.M.Mirziyoev to France. The museum exhibits are divided into 6 collections. The Oriental collection alone occupied 24 halls. There are thousands of artifacts related to the history of our country. In particular, the letter of Amir Temur to Charles VI, the candlestick made by Sahibkiran for the mausoleum of Ahmad Yassavi, ancient weapons, inscriptions and other artifacts testify to the great past. President of Uzbekistan Sh.M.Mirziyoev, who got acquainted with the sources directly related to the history of Uzbekistan in the museum, noted the need to organize regular exhibitions in cooperation with Uzbek-French museums, expand scientific cooperation between archaeologists and historians [15].
It is well known from history that the peoples of Europe, including the French, are very interested in the history and cultural heritage of Uzbekistan and its study. With this in mind, in 2021 the Louvre Museum plans to hold an exhibition dedicated to the history of Uzbekistan. This event will be the first exhibition dedicated to one of the countries of the Commonwealth of Independent States at the world-famous museum[16].

Cooperation is developing in the field of theater, as in all areas. The play "Iskandar" was staged at the A. Hidoyatov Theater in French-Uzbek collaboration. The role of Alisher Navoi was played by French actor François Shatto. The theater was staged in two languages - Uzbek and French. It was noted that it was well received by the general public and played an important role in the spiritual rapprochement of the two peoples, allowing them to get acquainted with their mutual cultures[17].

By the decree of the First President of the Republic of Uzbekistan, 1996 was declared the Year of Amir Temur. Since then, UNESCO, based in Paris, has paid great attention to this important historical event and celebrated its 660th anniversary internationally[18]. Representatives of embassies operating in Uzbekistan also took part in the event, which was held in Uzbekistan. Many major events in the field of Uzbek culture and history are now being held in cooperation with this prestigious organization[19].

Today, the signing of an intergovernmental agreement on cultural, scientific and technological cooperation between France and the Republic of Uzbekistan has allowed the development of longstanding ties in this area. The festival of French films, an exhibition dedicated to the present day of the French press and many other events are regularly held in our country.

In September 1996, the France-Uzbekistan Society and the Institute for the Study of Central Asia held a colloquium on "Temur's Legacy and Its Spread to the World" from Delhi to Istanbul and other topics. The last colloquium was attended by scientists from more than 10 countries. In assessing the activities of Timur, he noted his role not only in the development of world Islamic culture, but also in the creation of the culture of Timur's time. An association for the scientific study of the art and history of the Timurid period has been operating in France since 1988. [20].

In addition, the Avicenna-France Association, which studies and promotes the scientific heritage of the Uzbek scientist Abu Ali ibn Sino, who has made a worthy contribution to world medicine since 2004, is active. All this is a testament to the enormity of France's interest in Central Asian history.

As of 2018, French language is taught to more than 300,000 students in 1260 schools, colleges and lyceums, as well as 8 universities in the country. 
At the same time, Tashkent has a French Alliance, which has a rich library of more than 8,000 titles of French literature. It is obvious that in Uzbekistan, too, attention to French history and culture has long been formed and developed from year to year[21].

\section{CONCLUSION}

In conclusion, it should be noted that the cooperation of Uzbekistan with the developed countries of Europe during the years of independence has achieved great success in all areas, including trade, economic, cultural and humanitarian spheres. There is no doubt that such ties will contribute to the strengthening of interstate relations, the scientific and cultural rapprochement of our peoples and our development.

\section{REFERENCES}

1. Gulomov X.G. Xolliev A.G. International relations of the Republic of Uzbekistan with Great Britain and the USA (1991-2001gg). Tashkent, "Universitet", 2002. - p. 23.

2. Current archive of the Ministry of Foreign Economic Relations, Investments and Trade of the Republic of Uzbekistan. Information on trade, economic and investment status with the European Union. - p. 3;

3. According to the results of 2009, Germany took the 1 st place among the countries of the European Union in terms of trade turnover with the Republic of Uzbekistan.

4. States and international organizations. (Responsible editor f.f.d. Q.N. Nazarov). Tashkent, "Academy", 2005. - p. 164

5. Reception at the Oqsaroy // People's speech. - 2016. - 31 March.

6. Uzbekistan - Germany: on the way to strengthening cooperation with a new content // People's speech. 2019. 20 January.

7. In the same place.

8. Ministry of Foreign Affairs of the Republic of Uzbekistan // Sotrudnichestvo Respubliki Uzbekistan so stranami Evropy. http: //www.mfa.uz. - p. 2.

9. Uzbekistan-Germany: on the way to strengthening cooperation with a new content // People's speech. 2019. 20 January.

10. Matxoliqov K. History of cultural relations between the Republic of Uzbekistan and France / Interethnic relations and historical processes in Uzbekistan. Tashkent, 2000. p. 134.

11. The word of the people. 2002. 23 March.

12. Ministry of Foreign Affairs of the Republic of Uzbekistan // Ministry of Culture and Sports of the Republic of Uzbekistan // Fund $m-38$, list -1 , volume - 343. page - 65.

13. In the same place. Sheet 62.

14. Ministry of Foreign Affairs of the Republic of Uzbekistan // Fund - $m-2$, list - 1, volume - 48. sheet - 32 .

15. Uzbekistan-France: on the way to further expansion and strengthening of long-term cooperation // People's speech. 2018. 10 October.

16. Uzbekistan-France: on the way to further expansion and strengthening of long-term cooperation // People's speech. 2018. 10 October.

17. 17. Ministry of Foreign Affairs of the Republic of Uzbekistan // Fund - $m-2$, list - 1, volume - 48. sheet $-31$.

18. Ministry of Foreign Affairs of the Republic of Uzbekistan // Minutes of the meeting of the Board of Directors of "Uzbekistan-France" // F-m-2, list - №1, compilation - 164, page - 68.

19. Ministry of Foreign Affairs of the Republic of Uzbekistan // Natsionalnoy Assotsiatsii mezhdunarodnyx kulturno-prosvetitelskix svyazey Respubliki Uzbekistan.

20. Uzbekistan - France: Strategic prospects of cooperation // People's speech. 2018. 11 October.

21. Uzbekistan - France: Strategic prospects of cooperation // People's speech. 2018. 11 October. 